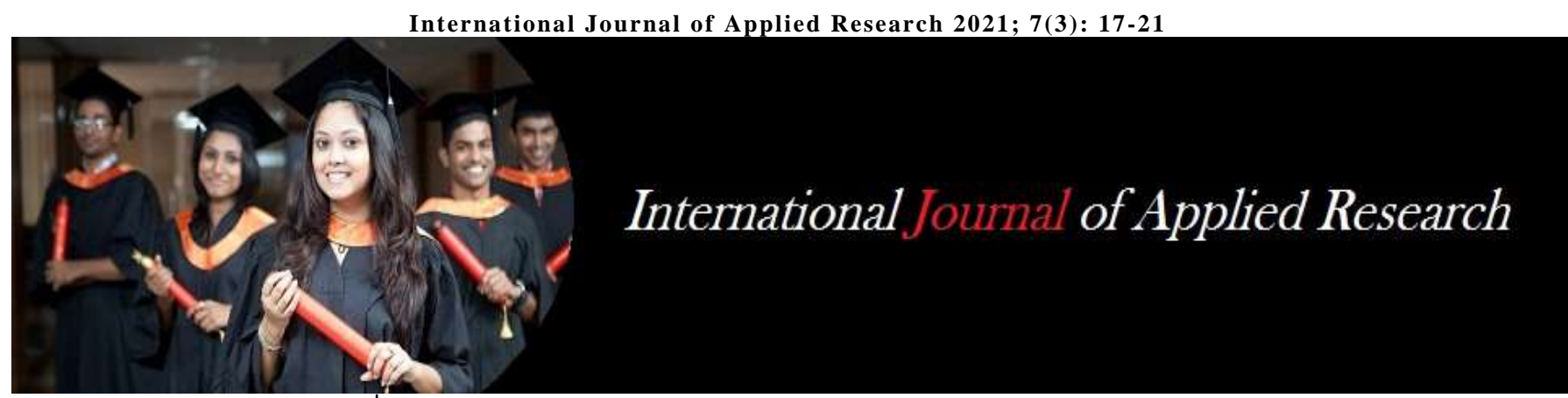

ISSN Print: 2394-7500

ISSN Online: 2394-5869

Impact Factor: 8.4

IJAR 2021; 7(3): 17-21

www.allresearchjournal.com

Received: 12-01-2021

Accepted: 15-02-2021

Supriya

Department of Nursing, Shri

Mata Vaishno Devi College of

Nursing, Katra, Jammu and

Kashmir, India
Corresponding Author:

Supriya

Department of Nursing, Shri

Mata Vaishno Devi College of

Nursing, Katra, Jammu and

Kashmir, India

\section{Impact of burden on quality of work life of nurses}

\section{Supriya}

DOI: $\underline{\text { https://doi.org/10.22271/allresearch.2021.v7.i3a.8343 }}$

\section{Abstract}

Quality of life is an important concept in the field of health. The aim of the study was to find the share of evident factors responsible for quality of work life of nurses. The selection of subjects was undertaken from 2010 through 2020. We searched for reviews that reported the quality of life of nurse and factors that affect their physical, mental as well as emotional health status which include original studies on Quality of life and general health of nurses. The studies utilize the WHOQOL-BREF and SF 36 questionnaire to assess the quality of life. In addition, The mean age of nurses in the review studies $58.6 \pm 15.02$ and $42 \pm 15$ years, respectively Majority of the included studies reported that the quality of life of nurses was related to care of burden, work productivity, job burnout, job satisfaction, performance obstacles, organizational effectiveness, and organizational commitment. Meanwhile $43 \%$ of the nurses were not satisfied with the quality of their work life however only $2 \%$ nurses reported that they had good quality of working life. The quality of life in the workplace was higher for people with permanent jobs $(p=0.007)$. The greater care burden had worse health related quality of life of nurses. Besides bodily pain, High-strain job, low scores on the emotional role and mental health were the ones most affected by psychosocial factors at work of nurses. It is concluded that majority of the nurses dissatisfied with the quality of life.

Keywords: Quality of life, nurse, workplace

\section{Introduction}

Nurses are professional health workers who play an important role in meeting the basic needs of patients. Professional nurses are required to be caring to patients, which is indicated by being there when patients are needed, adjusting to the patient's condition, and being directly involved in patient care. Quality of life (QOL) means the suitability of the material circumstances and the perception of the people and concerning their position in life. Stressors of nurses can be physiological, psychological, and behavioral leading to occupational stress related to mental and physical diseases that decrease satisfaction, well-being and QOL and put impact on quality care provided to their clients ${ }^{[1]}$. Quality of work life (QWL) is a complex entity influenced by, and interacting with, many aspects of work and personal life [5].

Quality of working life is an analyzing experience of work life, experience relates to job satisfaction and, personality and work stress. Inadequate staffing, leads difficulties in meeting patient needs. Nurses become disheartened about their professional unsatisfaction and wish to quit the nursing profession. Factors such as hospital size, number and type of patients, nurse's salary, hospital policies and physical environment may affect the nurses Quality of Working Life. Nurses in small size hospitals had greater satisfaction with their Quality of Working Life. Changes are required across the health care system to improve quality of life of nurses. Various studies are carried out globally for analyzing impact of burden on the quality of life of nurses. Nurses should enjoy a satisfactory quality of working life to be able to provide quality care to their patients ${ }^{[2]}$ raditionally measured job satisfaction of employees. Job satisfaction focuses on employees.

\section{Purpose of the study}

- This systemic review aims to receive the available studies on quality of life and nurses

- This systemic review aims to find the share of evident factors responsible for quality of life of nurses. 


\section{Methodology \\ Search strategies}

Systematic literature searches for publication referring to quality of work life of nurses and health related quality of life were conducted. To ensure broad coverage, the search term used was impact of burden on quality of life of nurses. We searched for reviews from publications published during the year 2010 to 2020 which covers PubMed, Medscape, Cochrane, Med-IND, Google Scholar and some other websites such as Research Gate, few Direct Websites. The search resulted in 50 publications. The terms used to search were following: quality of life of nurse, quality of work life and factors influencing quality of life of nurses

\section{Inclusion and exclusion criteria}

We searched for reviews that reported the quality of life of nurses and factors that affect their physical as well as mental health status which eventually affecting the quality of working life of nurses ${ }^{[1]}$ original studies which reported the Quality of life of nurses. ${ }^{[2]}$ Cross-sectional, comparative or longitudinal studies

The exclusion criteria were as follows: ${ }^{[1]}$ studies that did not report the quality of life of nurses [3] case reports, Editorials, [4] Studies with incomplete or unclear information.

\section{Data extraction and analysis}

The researchers searched, collected, extracted, and evaluated the information from each individual study included in the review as per the inclusion criteria. The information extracted from the individual studies included; the name of the author including the year of publication, where the study was conducted, research design of the study, attributes of the samples size, the type of instrument uses for data collection and the result of the studies. The search identified 50 studies on quality of life of nurses. International studies are included. Further, in depth screening was done for each individual study and the factors such as inclusion \& exclusion criteria and risk of bias was considered. Finally, 16 studies were accepted for the systematic review.

\section{Results}

The studies included in this review all used quality of working life of nurses and health related quality of life as approach. Of the 17 studies, many findings and observations were present in each study with regard to the broad objectives of this systematic review. The initial computerbased search identified 50 eligible articles, of 16 studies were included in the systematic review. It is important to observe that studies included for the reviewed that fulfilled inclusion criteria and its findings about the impact of burden on the quality of work life of nurses. All included studies had a cross-sectional design and other designs too. All the studies were carried out in a clinical setting. Researchers usually identify and enroll nurses who were working in various departments of the hospital under different kind of circumstances which include several domains that influences the Quality of life of nurses. Typically, most of the subjects have experienced physical mental as well as emotional factors, which ruined the quality of life of nurse.

Table 1: Shows 16 studies included for this review is present

\begin{tabular}{|c|c|c|c|c|}
\hline S. N. & Author (s) & Tool & Sample size & Result \\
\hline 1. & $\begin{array}{l}\text { Dr. Pamila N R Jathanna } \\
\text { Quality of life among nurses } \\
\text { working in different health care } \\
\text { setting in the state of Karnataka, } \\
\text { India, } 2014\end{array}$ & (WHOQOL-BREF) & 501 & $\begin{array}{c}\text { For overall physical health status of nurses was "ill" in } \\
\text { both the hospitals ( } 34 \% ; 23 \% \text { ) with significance at } 0.01 \\
\text { levels. The mean score for psychological domain was } \\
\text { least (41.83). Overall perception of QOL result showed } \\
\text { significance at } 0.01 \text { levels for all domains except for } \\
\text { psychological domain }{ }^{[1]} \text {. } \\
\end{array}$ \\
\hline 2. & $\begin{array}{c}\text { Tessy Treesa Jose \& Sripathy M. } \\
\text { Bhat } \\
\text { A descriptive study on quality of life } \\
\text { of nurses working in selected } \\
\text { hospitals of udupi and mangalore } \\
\text { districts karnataka, india, } 2014\end{array}$ & (WHO QOL-BREF) & $\begin{array}{c}1040 \text { registered } \\
\text { nurses }\end{array}$ & $\begin{array}{l}\text { Median score of QOL of nurses on overall perception of } \\
\text { quality of life and health were equal. Significant } \\
\text { association was observed between Quality of life and } \\
\text { marital status, and monthly income, area of work, } \\
\text { working hours and total years of experience }{ }^{[6]} \text {. }\end{array}$ \\
\hline 3. & $\begin{array}{c}\text { Papatya Karakurt, Evaluation of } \\
\text { Care Burden and Quality of Life of } \\
\text { Caregivers of Patients with Stroke, } \\
2018\end{array}$ & the Barthel Index & 121 & $\begin{array}{c}\text { The patients demonstrated poor health on the SF-36, } \\
\text { with a mean score of } 52.91 \pm 14.25 \text {. The average burden } \\
\text { score of caregivers was } 48.66 \pm 10.61 \text {. A significant } \\
\text { negative correlation was found between QOL and } \\
\text { Caregiver burden }{ }^{[7]} \text {. }\end{array}$ \\
\hline 4. & $\begin{array}{l}\text { Haleh Jafari, Azita Ebrahimi. The } \\
\text { relationship between care burden } \\
\text { and quality of life in caregivers of } \\
\text { hemodialysis patients, } 2018\end{array}$ & $\begin{array}{c}\text { Novak \& Guest Care } \\
\text { burden } \\
\text { Questionnaire, and } \\
\text { WHOQOL-BREF } \\
\text { Quality of Life } \\
\text { Questionnaire } \\
\text { quality of their work } \\
\text { life due to care } \\
\text { burden }\end{array}$ & 246 caregivers & $\begin{array}{l}\text { In total, } 37.4 \% \text { of caregivers were experiencing high and } \\
\text { very high levels of care burden and } 42.7 \% \text { of them were } \\
\text { experiencing a moderate level of care burden. There was } \\
\text { a significant and negative correlation between the total } \\
\text { scores of care burden and quality of life ( } r=-0 \text {. } \\
436, P<0.001) \text {. The factors influencing care burden } \\
\text { included variables such as; level of patient's caring } \\
\text { capability, the patient's incidence of other chronic } \\
\text { diseases, and the age of the caregiver. So that, in case of } \\
\text { reduced patient's capability in self-care }{ }^{[4]} \text {. }\end{array}$ \\
\hline 5. & \begin{tabular}{|c|} 
Paula cristina Nogueira, Burden of \\
care and its impact on health-related \\
quality of life of caregivers of \\
individuals with spinal cord injury, \\
2012 \\
\end{tabular} & $\begin{array}{l}\text { HRQOL and the } \\
\text { Caregiver Burden } \\
\text { Scale (CBScale) for } \\
\text { care burden } \\
\text { (worse HRQOL.) } \\
\end{array}$ & 59 & $\begin{array}{l}\text { Tetraplegia and secondary complications stand out } \\
\text { among the clinical characteristics that contributed to } \\
\text { greater care burden and worse HRQOL. Association } \\
\text { between care burden with HRQOL revealed that the } \\
\text { greater the burden the worse the HRQOL }\end{array}$ \\
\hline 6. & Roselaine,Association between & Self-administered & 143 & Associations showed statistical significance in better \\
\hline
\end{tabular}




\begin{tabular}{|c|c|c|c|c|}
\hline & $\begin{array}{l}\text { nurses' quality of life and work } \\
\text { environment, } 2018\end{array}$ & $\begin{array}{c}\text { instruments. } \\
\text { quality of life scores } \\
\text { for those satisfied } \\
\text { with the salary }\end{array}$ & & $\begin{array}{l}\text { quality of life scores for those satisfied with the salary } \\
\text { and with work time of over six years, and lower scores } \\
\text { for those working in closed and special units, for } 36-40 \\
\text { hours a week and who were promoted and evaluated } \\
\text { positively in the previous } 12 \text { months }{ }^{[13]} \text {. }\end{array}$ \\
\hline 7. & $\begin{array}{c}\text { Amanda Aparecida Silva, José Maria } \\
\text { Pacheco de Souza, Health-related } \\
\text { quality of life and working } \\
\text { conditions among nursing providers, } \\
2010\end{array}$ & $\begin{array}{l}\text { self-administered } \\
\text { questionnaires }\end{array}$ & $\begin{array}{c}696 \text { registered } \\
\text { nurses }\end{array}$ & $\begin{array}{c}\text { Around } 22 \% \text { of the sample was found to be have high } \\
\text { strain and } 8 \% \text { showed an effort-reward imbalance at } \\
\text { work. The dimensions with the lowest mean scores in } \\
\text { the SF-36 were vitality, bodily pain and mental health. } \\
\text { High-strain job, effort-reward imbalance (ERI>1.01), } \\
\text { and being a registered nurse were independently } \\
\text { associated with low scores on the role emotional } \\
\text { dimension. Those dimensions associated to mental } \\
\text { health were the ones most affected by psychosocial } \\
\text { factors at work }{ }^{[8]} \text {. }\end{array}$ \\
\hline 8. & $\begin{array}{c}\text { Tayebeh Moradi, Farzaneh } \\
\text { Maghaminejad, Quality of Working } \\
\text { Life of Nurses and its Related } \\
\text { Factors, } 2012\end{array}$ & $\begin{array}{l}\text { Walton's quality of } \\
\text { work life } \\
\text { questionnaire. }\end{array}$ & 200 nurses & $\begin{array}{l}\text { The results of the study showed that } 60 \% \text { of nurses } \\
\text { reported that they had moderate level of quality of } \\
\text { working life while } 37.1 \% \text { and } 2 \% \text { had undesirable and } \\
\text { good quality of working life, respectively. A significant } \\
\text { relationship was found between variables such as } \\
\text { education level, work experience, and type of hospital } \\
\text { with quality of working life score }(P<0.05)^{[9]} \text {. }\end{array}$ \\
\hline 9. & $\begin{array}{c}\text { Celalettin SerinkanKeziban } \\
\text { KAYMAKÇI, Defining the Quality } \\
\text { of Life Levels of the Nurses: A } \\
\text { Study in Pamukkale University, } \\
2013 \\
\end{array}$ & $\begin{array}{l}\text { questionnaire short } \\
\text { form SF-36 scale }\end{array}$ & 87 nurses & $\begin{array}{l}\text { The nurses have children, and 3, } 4 \text { family members, } \\
\text { QOL score is higher all dimensions than except general } \\
\text { health score. Day shift nurses have higher general health } \\
\text { than other dimensions }{ }^{[10]} \text {. }\end{array}$ \\
\hline 10. & $\begin{array}{l}\text { Y. Kowitlawkul RN, Investigating } \\
\text { nurses' quality of life and work-life } \\
\text { balance statuses in Singapore, } 2014\end{array}$ & $\begin{array}{c}\text { validated } \\
\text { questionnaires }\end{array}$ & 1040 Nurses & $\begin{array}{l}\text { Social support and sense of coherence were found to be } \\
\text { significant predictors for high quality of life in all } \\
\text { domains. Most nurses in this study spent more time on } \\
\text { work than their private lives. However, there was no } \\
\text { significant difference in job satisfaction among the four } \\
\text { groups of nurses' proportions of percentages of actual } \\
\text { time spent on work and private life }{ }^{[11]} \text {. } \\
\end{array}$ \\
\hline 11. & $\begin{array}{c}\text { Sandra Joković, Maja Račić, Quality } \\
\text { of life of nurses, } 2017\end{array}$ & $\begin{array}{l}\text { questionnaire of } \\
\text { health assessment } \\
\quad(\mathrm{SF}-36)\end{array}$ & 100 nurses & \begin{tabular}{|l} 
The highest percentage of respondents (67\%) belongs to \\
the category of excellent physical functioning. 52\% of \\
respondents have excellent social functioning, $47 \%$ have \\
a good level of performance. Thirty percent of \\
respondents have significant limitations due to \\
emotional problems. Socio demographic characteristics \\
significantly affect the quality of life of nurses \\
\end{tabular} \\
\hline 12. & $\begin{array}{l}\text { Güler Cimete }{ }^{[1]} \text {, Nimet Sevgi } \\
\text { Gencalp, Quality of life and job } \\
\text { satisfaction of nurses, } 2013\end{array}$ & $\begin{array}{l}\text { Minnesota } \\
\text { Questionnaire and } \\
\text { QOL by means of } \\
\text { WHOQOL-BRIEE }\end{array}$ & 501 nurses & \begin{tabular}{|c|} 
The results demonstrated a positive correlation between \\
job satisfaction and QOL. It was also found that job \\
satisfaction and QOL scores of nurses showed a \\
significant difference according to their age, economic \\
level, marital status, duration of working life, and \\
position at work \\
$14]$
\end{tabular} \\
\hline 13. & $\begin{array}{c}\text { María Olga Quintana } \\
\text { Zavala, 2 Tatiana Paravic } \\
\text { Klinj,Quality of life in the workplace } \\
\text { for nursing staff at public healthcare } \\
\text { institutions, } 2016\end{array}$ & $\begin{array}{l}\text { CVT-GOHISALO } \\
\text { instrument }\end{array}$ & 345 nurses & $\begin{array}{c}\text { The quality of life in the workplace was higher for } \\
\text { people with permanent contracts }(p=0.007) \text { who did not } \\
\text { engage in other remunerative activities }(p=0.046) \text {. } \\
\text { Differences in the quality of life in the workplace were } \\
\text { observed depending on the institution where the subjects } \\
\text { worked }(p=0.001)^{[15]}\end{array}$ \\
\hline 14. & $\begin{array}{l}\text { Kyunghee Kim, Yonghee Han, } \\
\text { Professional Quality of Life and } \\
\text { Clinical Competencies among } \\
\text { Korean Nurses, } 2015\end{array}$ & $\begin{array}{l}\text { self-administered } \\
\text { questionnaires }\end{array}$ & 335 nurses & \begin{tabular}{|} 
There were significant differences in age, marital status, \\
religion, educational status, and position between \\
clusters. Results also revealed that nurses with high \\
compassion satisfaction and low compassion \\
fatigue (burnout, secondary traumatic stress) tended to \\
have higher clinical competence ${ }^{[16]}$. \\
\end{tabular} \\
\hline 15. & $\begin{array}{c}\text { Aline Moraes da Silva,Occupational } \\
\text { Stress and Quality of Life in } \\
\text { Nursing, } 2016\end{array}$ & Job Strain Scale & $\begin{array}{l}273 \text { nursing } \\
\text { professional }\end{array}$ & $\begin{array}{c}\text { It was found that } 60.8 \% \text { of the participants see the high } \\
\text { demand of work, } 71.8 \% \text { high control on the developed } \\
\text { activity and } 85.5 \% \text { low social support. Related to eight } \\
\text { dominant of quality of life, the most damaged are: pain } \\
\text { ( } \mu=61.87 \text { ) and vitality }(\mu=62.25) \text {. It was concluded } \\
\text { that although in most sample experiences an } \\
\text { intermediary risk situation to stress, the quality of life } \\
\text { showed a damaged }{ }^{[17]} \text {. }\end{array}$ \\
\hline 16. & \begin{tabular}{|c|} 
Lolemo Kelbiso, Determinants of \\
Quality of Work Life among Nurses \\
Working in Hawassa Town Public \\
Health Facilities, South \\
\end{tabular} & $\begin{array}{c}\text { Structured } \\
\text { Questionnaire. } \\
\text { quality of their work } \\
\text { life }\end{array}$ & 253 nurses & $\begin{array}{l}\text { The study showed that } 67.2 \% \text { of the nurses were } \\
\text { dissatisfied with the quality of their work life. We found } \\
\text { that educational status, monthly income, working unit, } \\
\text { and work environment were strong predictors of quality }\end{array}$ \\
\hline
\end{tabular}




\begin{tabular}{|c|c|c|c|c|}
\hline & & & of work life among nurses ${ }^{[18]}$. \\
\hline $17 . \quad \begin{array}{c}\text { Pouran Raeissi Quality of work life } \\
\text { and factors associated with it among } \\
\text { nurses in public hospitals, Iran, 2019 }\end{array}$ & 2391 nurses & $\begin{array}{c}\text { The mean score for total quality of work life was 2.58, } \\
\text { indicating a low level of self-reported quality of work } \\
\text { life, with 69.3\% of nurses dissatisfied with their work } \\
\text { life. The major influencing factors were inadequate and } \\
\text { unfair payment, lack of solving staff problems by } \\
\text { organization and poor management support, job } \\
\text { insecurity, high job stress, unfair promotion policies, } \\
\text { and inadequate involvement in the decision-making. } \\
\text { Significant predictors in the multivariate analysis for } \\
\text { lower quality of work life were male gender, being } \\
\text { single, older age, having lower educational levels, and } \\
\text { working in teaching hospitals }\end{array}$ \\
\hline${ }^{[3]}$.
\end{tabular}

\section{Discussion}

In the present study the authors documented the quality of life of nurses and impact of burden on it. The purpose of the systematic review is to analyze the predators associated with quality of life work as well as on the personal life of nurses. We have synthesized 50 studies during the last 10 years (2010 to 2020). The details of the 16 studies included for this review is present at Table No. 01. The studies were conducted in various countries and its vided distribution ensures the conformity of the results of this study.

In the present systematic review data has been collected from various past studies conducted on the quality of life of nurses. The seven studies $(1,4,7,8,10,12 \& 13)$ have been included physical and mental health status of nurses which put impact on quality of life of nurses. Six studies $(6,9,11$, $14,15 \& 16)$ depicted the determinants of the quality of life of nurses. Most nurses in this study spent more time on work than their private lives. However, there was no significant difference in job satisfaction among $t$ nurses' proportions of percentages of actual time spent on work and private life.

As well these studies utilizes the WHOQOL-BREF, Walton's quality of work life and SF 36 questionnaire to assess the quality of life ; along with this other domains like pain and vitality of nurses (Job Strain Scale), CVTGOHISALO instrument for quality of nurses at workplace, Minnesota Questionnaire for job satisfaction and quality of life were also used. The mean age of nurses in the review studies $58.6 \pm 15.02$ and $42 \pm 15$ years, respectively.

The studies $(1,7,8,12)$ which revealed the physical and mental health status has the great impact on the quality of life of nurses however psychosocial factors were the main predators of quality of life of nurse. The Nurses working for Day shift have higher general health than night shift nurses. The dimensions with the lowest mean scores in the SF-36 were vitality, bodily pain and mental health. High-strain job, effort-reward imbalance and nurse were independently associated with low scores on the role emotional dimension. It was also reported that Association between care burdens with HRQOL revealed that the greater the burden the worse the health related Quality of life.

The results of these studies $(6,8,9,13,14,16 \& 18)$ showed that in general, educational status, monthly income, working unit, and work environment were strong predictors of quality of work life among nurse also revealed that QOL scores of nurses showed a significant difference according to their age, economic level, marital status, duration of working life, and position at work. However, it was also showed that statistical significance in better quality of life scores for those satisfied with the wages and with work experience over six years, and lower scores for those working with special units, for 36-40 hours a week and were promoted and evaluated positively for the last 12 months Majority of the included studies reported that the quality of life of nurses was related to care of burden, work productivity, job burnout, job satisfaction, performance obstacles, organizational effectiveness, and organizational commitment. Meanwhile $43 \%$ of the nurses were dissatisfied with the quality of their work life however only $2 \%$ nurses reported that they good of quality of working life The quality of life in the workplace was higher for people with permanent jobs $(p=0.007)$. Differences in the quality of life in the workplace were observed depending on the institution where the subjects are working $(p=0.001)$ Increased work load at workplace than put ruinous effect on their quality life of nurses.

Numerous studies described about the physical, mental as well as emotional domains of quality of life of nurses. The greater care burden had worse health related quality of life of nurses. Besides bodily pain, High-strain job, low scores on the emotional role and mental health were the ones most affected by psychosocial factors at work of nurses.

\section{Conclusion}

Attestation indicate important Quality of working life and health related quality of life impairments in nurses; Quality of working life had influenced all the domains but it had major impact on the physical mental as well as emotional domain is directly associated with their Higher Education, Income, married life, permanent jobs, job satisfaction, working experience, and Increased Age. Consequently, nurses should be acquainted with domains which affected the quality of life (QoL). It is concluded that majority of the nurses dissatisfied with the quality of life.

\section{References}

1. Jathanna PN, D'Silvw J. Quality of life among nurses working in different health care setting in the state of Karnataka, India. Chrismed J Health Res 2014;1:241-4

2. Moradi T, Maghaminejad F, Azizi-Fini I. Quality of working life of nurses and its related factors. Nursing and midwiferystudies 2014;3(2):e19450

3. Raeissi P, Rajabi MR, Ahmadizadeh E, Rajabkhah K, Kakemam E. Quality of work life and factors associated with it among nurses in public hospitals, Iran. J Egypt Public Health Assoc 2019;94(1):25.

4. Jafari H, Ebrahimi A, Aghaei A et al. The relationship between care burden and quality of life in caregivers of hemodialysis patients. BMC Nephrol 2018;19:321. https://doi.org/10.1186/s12882-018-1120-1

5. Almalki MJ, FitzGerald G, Clark M. Quality of work life among primary health care nurses in the Jazan 
region, Saudi Arabia: a cross-sectional study. Hum Resour Health 2012;10:30. https://doi.org/10.1186/1478-4491-10-30Tessy

6. Treesa Jose, Sripathy Bhat M. A descriptive study on quality of life of nurses working in selected hospitals of Udupi and Mangalore districts Karnataka, India. Nitte University Journal of Health Science 2014;4(2).

7. Karakurt P, Unsal A. Evaluation of Care Burden and Quality of Life of Caregivers of Patients with Stroke. International Journal of Caring Sciences 2018;11(1):529.

8. Silva AA, Souza JM, Borges FN, Fischer FM. Healthrelated quality of life and working conditions among nursing providers. Rev Saude Publica 2010;44(4):71825. DOI: $10.1590 / \mathrm{s} 0034-89102010000400016$. PMID: 20676562.

9. Moradi T, Maghaminejad F, Azizi-Fini I. Quality of working life of nurses and its related factors. Nursing and midwifery studies 2014;3(2):e19450.

10. Celalettin Serinkan, Keziban Kaymakçi. Defining the Quality of Life Levels of the Nurses: A Study in Pamukkale University, Procedia - Social and Behavioral Sciences 2014;89:580-584.

11. Kowitlawkul Y, Yap SF, Makabe S, Chan S, Takagai J, Tam WWS, Nurumal MS. Investigating nurses' quality of life and work-life balance statuses in Singapore. International Nursing Review 2019;66:6169.

12. Nogueira PC, Rabeh SA, Caliri MH, Dantas RA, Haas VJ. Burden of care and its impact on health-related quality of life of caregivers of individuals with spinal cord injury. Rev Lat Am Enfermagem 2012;20(6):1048-56.

13. Santos Roselaine Raimundo dos, Paiva Miriam Cristina Marques da Silva de, Spiri Wilza Carla. Association between nurses' quality of life and work environment. Acta paul. enferm. [Internet] 2018;31(5): 472-479.

14. Cimete G, Gencalp NS, Keskin G. Quality of life and job satisfaction of nurses. J Nurs Care Qual 2003;18(2):151-8. doi: 10.1097/00001786-20030400000009. PMID: 12680602.

15. Zavala MO, Klinj TP, Carrillo KL. Quality of life in the workplace for nursing staff at public healthcare institutions. Revista latino-americana de enfermagem 2016;24:e2713. https://doi.org/10.1590/1518-8345.1149.2713

16. Kyunghee Kim, Yonghee Han, Yeunhee Kwak, Ji-su Kim. Professional Quality of Life and Clinical Competencies among Korean Nurses, Asian Nursing Research 2015;9(3):200-206.

17. Silva, Aline Moraes da, Guimarães, Liliana Andolpho Magalhães. Occupational Stress and Quality of Life in Nursing. Paidéia (Ribeirão Preto) 2016;26(63):6370. https://doi.org/10.1590/1982-43272663201608 (17

18. Lolemo Kelbiso, Admasu Belay. Determinants of Quality of Work Life among Nurses Working in Hawassa Town Public Health Facilities, South Ethiopia: A Cross-Sectional Study. Nursing Research and Practice 2017. 